\title{
Development of Social Studies Learning Model Based on Local Wisdom in Improving Students' Knowledge and Social Attitude
}

\author{
Sarnely Uge \\ Department of Elementary Education, State University of Jakarta, Indonesia, \\ sarnely_u@yahoo.com
}

Amos Neolaka

Prof., State University of Jakarta, Indonesia, aneolaka@unj.ac.id

\section{Mahmuddin Yasin}

Prof., State University of Jakarta, Indonesia, myasin.myconsulting@ gmail.com

This study reports the design results of developing model of social studies learning based on local wisdom. Learning design adapted to learning needs in elementary school. The presentation report contains the results of expert evaluation, teacher and student assessments and assessment of the results of the implementation of the product learning model developed. The Product model produced is seen to be in accordance with learning needs. The results of the development research showed that: first, testing the effectiveness model of social studies learning based on local wisdom is feasible from an expert perspective; second, testing the effectiveness model of social studies learning based on local wisdom is feasible from the user's perspective; third, testing the effectiveness model of social studies learning based on local wisdom can improve the knowledge and social attitudes students class IV at SDN 6 Katobu and SDN 3 Batalaiworu in odd semester of the school year 2017/2018 in the Muna District Southeast Sulawesi Province. Overall, the author concluded that social studies learning based on local wisdom was a regeneration of knowledge of the values of local wisdom in students from an early age, so become cultured and have guidance in their attitude. Thus, created noble knowledge and character.

Keywords: social studies, local wisdom values, social knowledge, social attitude, development research

\section{INTRODUCTION}

Education in the region must grow and develop within the cultural context in which the educational institution is located. Knowledge of the local culture for educators is 
certainly a prerequisite. The meaning of local wisdom in the world of education is very less (Tilaar, 2012). Local Values are beginning to fade and be abandoned, thereby diminishing the student's understanding of the value of local cultural values.

The school as the most environmentally responsible for education, has not yet reflected as a child's counselling agency. Learning is schools tends to focus on existing textbooks, teachers as the main learning source, teacher dominated learning process, students only listen and memorize so it clears what is learned to the extent of cognition does not consider aspects of attitude. Many schools use one measurement to evaluate student progress using standardized tests that only measure knowledge (Senge, CambronMcCabe, Lucas, Smith, Dutton, \& Kleiner, 2002).

Local wisdom is seen relevant to social studies, because local wisdom is a cultural product that includes philosophy, values, norms, ethics, rituals, beliefs, habits, customs, and so on Rohmadi \& Hartono, 2011, p. 284), whereas according to Seefeldt, Castle, \& Falconer (2010), the concept of social studies introduces the child to a different idea, belief, value, and culture even related to the teaching of children's values and attitudes. This indicated local wisdom can be used as a source of material and values that serve as the basis of the direction of acting and behaving in the daily life.

The results of the field study showed that the social studies learning process in elementary schools' number 6 Katobu and elementary school number 3 Bataliworu Muna Discrit tends to be non-contextual. The material presented in the textbook is abstract so that it only refers on the cognitive domain. In addition, there is no integration of local wisdom values in social studies material. Students are less interested, less enthusiastic, bored and sleepy when studying. In addition, there were also problems with students' very low social attitudes (mocking, insulting, fighting, not listening to advice, disrespect of others and lack of courtesy). Teaching learning process used traditional method. The use of traditional methods does not give meaning because it does not take into account the psychological attitudes and students (Guvercin \& Verbovskiy, 2014). This finding has not yet maximal in social attitude in elementary school class IV are very Low.

Therefore, one of the right strategies in dealing with the problems that occur in social studies learning is to conduct development research. The learning model that is developed is viewed according to the needs in the field that is based on local wisdom. Researcher believes that the model developed based on local wisdom can improve the quality of learning in terms of students' knowledge and social attitudes in Muna District of Southeast Sulawesi Province.

\section{Research Question}

Based on the results of observations in the field with a number of problems that are very crucial in learning social studies in elementary schools in Muna, it needs the right solution to improve them. Thus, this raises the following research questions:

1. Is the local wisdom based social studies learning model feasible from an expert perspective? 
2. Is the local wisdom based social studies learning model feasible from user's perspective?

3. Is the local wisdom based social studies learning model improve students' knowledge and social attitude?

\section{REVIEW OF LITERATURE}

\section{The Nature of Social Studies Learning}

Learning as a social activity (Carrington \& Macarthur, 1968). Learning social studies is related to civics education (Boyle-Baise \& Zevin, 2009). Social studies includes learning the history, culture and interactions of people in the world (Wade, 2007). Learning about the environment, skills and attitudes of human beings needs in living social life and content and processess of social studies can be integrated into activities where every child can participate (Mayesky, 2012). The concept of social studies introduces children to different ideas, beliefs, values and cultures even to the teching of children's values and attitudes (Seefeldt et al., 2010). Many subjects and skills are taught in school but social studies is focused on attitudes and values (Parker, 2009).

The basic Foundations of social studies aims to enable students to explore and observe their social and cultural environment systems (Kumari \& Bhaskararao, 2004). Social studies aims to provide opportunities for children to learn about themselves and others (Jackman, 2010). Social studies knowledge is a child learning behavior and knowledge about the actions of people who are shown with people around them (Beaty, 2010). The objectives of social studies education subjects based on the national education standard (2006), (SD/Madrasyah ibtidaiyah/MI) are: (1) recognize concepts related to community life and environment, (2) have basic skills for logical and critical thinking, curiosity, inquiry, problem solving in social life, (3) have commitment and awareness of social values and humanity, (4) ability to communicate, cooperate and compete in society diverse, locally, nationally and globally.

Social studies learning is one of the subjects that educate children to become citizens who are able to develop knowledge, attitudes and values of harmony in society. But the problem found in the field that student's knowledge and social attitudes in social attitudes learning are still low. The average score of students has not yet the minimum completeness criteria.

The teacher revealed that social attitude of student also still far from society expectation student tends to no longer respect others, likes to mock each other, insult and fight among students. The same thing is expressed by one of the indigenous leaders that student do not respect others and no longer have the customs of courtesy. The behavioral symptoms of children showing the misbehavior must be detected as early as possible, because if the behavior has crossed the line, then finally the children can no longer face himself in a healthy life (Gunawan, 2010).

Problem found indicate the existence of material needs that are in accordance with the reality of student life both physically, psychologically and culturally. Not only that, but it takes material to make student better. One of them is by integrating local wisdom as a 
supporting material in learning attitudes from an early age. These conditions emphasize the importance of the role elementary school social studies teachers in improving the quality of social studies learning. Improvement efforts can be started from the learning process that is designed by the teacher systematically so as to be able to create a quality learning system. However, the constraints of teachers tend to not understand the design of the learning model. So that it is not maximally developed a learning model which is in accordance with the conditions and characteristics of students.

\section{Local Wisdom Values}

Value is feelings about what should be considered good, bad moral or immoral; the ideals that people long for but do not necessarily pursue (Crapo, 2002). Values is an evaluative component of our beliefs that incorporates utility, goodness, aesthetics and satisfaction (McAdams \& Mulyana, 2012). So, values are normative, information members of the cultural what is good or bad, right or wrong, what we struggle for, what we are afraid of, etc. According to Parker, (2009), values are essential to democratic citizenship.

The values of local wisdom can be regarded as the value of cultural values in a community or related to culture in society. Cultural values effect how children express their emotion and how they interact with their friends (Miller, 2012). Local wisdom or local culture is an important source of value in people's lives. Almost all indigenous and tribal cultures in the country are inspired by values and ideas rooted in the beliefs that live in society, the values of religious and spritual ethics that effect the behavior of socio-cultural life and the value of religious (Nata, 2014).

Local wisdom is material (traditional house, traditional cloting, craft arts, regional specialties, etc) and non material such as the value of philosophy that is believed to be the guideline to carry out life activities in order to maintain the survival both personally, groups and communities. Local wisdom concerns knowledge, understanding, orinsight and customs and habits embodied in the wisdom based on the values and cultural norms held by the community (Ostrome, 1993). The function of local wisdom to anticipate, filter and even transform the various forms of influence outside so that it continues to characterize its local community. The stronger resilience of local wisdom then the community concerned more stable (Ratna, 2011). The value of local wisdom is a hereditary value passed on to the next generation and serve as a guide in regulating the mindset, how to act and behave.

\section{Cognitive}

Knowledge becomes prominent in various education and daily living conditions as a basis for adjustment in the professional environment, self education, and professional development of a person (Sabirova, 2016). Cognitive processes include the way children think, develop an understanding of the world as what they learn to solve problems (Dodge, Trister, Rudick, \& Berke, 2006). The cognitive domain includes a focus on knowledge outcomes and capabilities requiring memory, thought and reasoning processes (Nitko, 2001). Knowledge is information that is known by humans from the process of seeking or learning outcomes that are used to understand something. 


\section{Social Attitude}

The domain of attitudes includes the results of feelings, interests, attitudes, trends and emotions (Nitko, 2001). Basically attitude is believed to affect behavior. Categorizing the cognitive component of attitudes are beliefs, thoughts and attributes related to attitude objects whereas the affective component of attitudes is the feeling or emotion associated with the object of attitude (Hewston, Stroebe, \& Jonas, 2012).

Social attitudes as patterns of behavior, setor anticipatory tendencies, tendency to adapt to certain social situations, or more simply a conditioned response to social stimuli (Lapiere, 2010). Social attitudes that are not brought from birth but can be learned and formed during the development of one's life that takes place through social interaction both in groups and outside the group in connection with a particular object. Examples of social attitudes are honest, discipline, responsibility, tolerance, mutual cooperation, courage, confidence and so on. Social attitudes are a tendency to act positively or negatively on a particular social situation.

\section{METHOD}

\section{Research Methods}

The method used in this research was research and development (R\&D) method. Research data collected through interview, questionnaire, test results and observation. Research and development of learning model was designed using research and development model of Borg and Gall (1983) and combined with an instructional development model by Alwi Suparman (2014) which was modified by the researcher. The Borg and Gall model is used only in the preliminary research step and the product development model is designed following the step of the instructional development model (MPI).

\section{The Design Phase of The Model}

The process of designing the model is divided into five namely : (1) preliminary study includes literature review and field observation; (2) model development includes the process of composing learning materials syllabus, textbook, learning strategy, lesson plan, assessment instrument of knowledge test and social attitude of student; (3) validation and model revisions include feasibility tests from an expert's point of view consisting; (4) model trial include feasibility tests from the user's point of view. The trial was conducted in two stages one-on-one and small group trial; (5) model implementation phase includes the use of model products in regular classroom learning. Implementation is carried out for one semester from August to December 2017 using experimental and control class design.

\section{Research Subject}

This research was research and development. The research subject was all participants involved in each stage of the design model. The subject during the preliminary study involved 3 elementary schools, 3 teachers and 3 students. The subject when model validation involved 3 material experts, 3 graphic and image design experts, 3 linguists, 3 
locality experts, 3 experts of knowledge test instruments and 3 experts of social attitude test instruments. The subject during the trial one-on-one model involved 2 elementary schools, 6 students in the high, medium, low category and 2 teachers. The subject during the trial small group model involved 6 elementary schools, 36 students in the high, medium, low category and 6 teachers. The subject when implementing model involved 2 elementary schools, 4 classes (2 experimental classes and 2 control classes). Experimental class involves elementary school number 6 Katobu class IVA consist of 24 students and elementary school number 3 Batalaiworu class IVA consists of 23 students. The control class involves elementary school number 6 Katobu class IVB consists of 21 students and elementary school number 3 Batalaiworu class IVB consists of 20 students. A total of 47 students of the experimental class and 41 students of the control class.

The selection of school for the location of the preliminary study, trial of the model and model test location using purposive sampling techniques or determining the sample with certain considerations. This Consideration is based on school accreditation. So school are chosen that represent accreditation $\mathrm{A}, \mathrm{B}$, and $\mathrm{C}$.

\section{Data, Data Sources and Data Collection Tools}

The research data consisted of pre-research data, model validation data, model trial data and model implementation data. The data collection tool used interview guides, questionnaire, tests and observation data. The data source consists of teachers, students, material experts, graphic and image design experts, language experts, locality experts, knowledge test instrument experts and social attitude tests instrument experts.

\section{Research Instrument}

The research instrument consists of three components namely the product assessment instruments by experts, the product assessment instruments by the user (teacher and student), and the test instruments of students' social studies knowledge and social attitude. Expert instruments contain product assessment in the terms of content, presentation, language and layout. User's instruments contain product assessment in the terms of content, language and layout. Special instruments that will be distributed to students are arranged in a simple manner according to the level of development. Instrument test used was a multiple choice 40 questions. Social attitude is arranged in the form of statements and observed by the teacher during the course of one semester. Indicators are honest, disciplined, responsible, tolerant, mutual, polite and confident.

\section{Data Analysis Technique}

Data analysis techniques are divided into three stages. First, analysing data on expert test results (material, language, graphic design, local wisdom) on the product model developed. The expert appraisal data was analysed using the Lawshe formula to determine the value of the Content Validity Ratio (CVR) with the categories: (a) if the CVR value $<0$ then the item was declared not good, (b) if the CVR value $=0$ then the item was declared not good, (c) if the value CVR> 0 then the item is declared good. The material expert assessment consists of 59 statement items, the linguist consists of 14 
statement items, the graphic design expert consists of 12 statements and the local wisdom expert consists of 10 statement items.

Second, analysing the results of the trial data (one-on-one and small group trials). The trial assessment data was analysed using the Lawshe formula to determine the value of the Content Validity Ratio (CVR) with the categories: (a) if the CVR value $<0$ then the item was declared not good, (b) if the CVR value $=0$ then the item was declared not good, (c) if CVR value> 0 then the item is declared good. The assessment of one-on-one and small-group trials by each student consists of 10 statement items and by the teacher each consisting of 33 statement items.

Third, techniques of analysis of knowledge data and students' social attitudes using inferential statistics. The data testing stages are (1) the data normality test using the lilifors test to prove whether the data group comes from the normal distributed population, (2) the data homogeneity test using bartlett test to prove whether the data group has the same variance, (3) T test as the final test to compare the effectiveness of the model product developed with the convensional model.

\section{FINDINGS}

\section{Research Question 1}

\section{The Data of Expert Test Results}

The assessment of material experts, languages, graphic design and product locality experts on the model developed includes the assessment of content, presentation, language and layout. The results of assessment data analysis 3 material experts from 59 statement items showed the value of CVR $>0$. The value of CVR for each statement item amounted to 1,00 which means that each item was declared good. The results of assessment data analysis 3 linguists' experts from 14 statement items showed the value of CVR > 0 . The value of CVR for each statement item amounted to 1,00 which means that each item was declared good. The results of assessment data analysis 3 graphic design experts from 12 statement items showed the value of CVR $>0$. The value of CVR for each statement item amounted to 1,00 which means that each item was declared good. The results of assessment data analysis 3 locality experts from 10 statement items showed the value of CVR $>0$. The value of CVR for each statement item amounted to 1,00 which means that each item was declared good. The results of assessment data analysis 3 knowledge test instrument experts from 40 items of questions showed the value of CVR $>0$. The value of CVR of 2 question items amounted to 0,33 and 38 question items amounted to 1,00 which means that each item was declared good. The results of assessment data analysis 3 social attitude instrument experts from 20 items of statement showed the value of CVR > 0 . The value of CVR of 2 statement items amounted to 0,33 and 18 statement items amounted to 1,00 which means that each item was declared good.

From the results of expert evaluation, it can be concluded that the products of the social studies learning model based on local wisdom are developed as feasible for use in regular learning. 


\section{Research Question 2}

The Data of User Trial Results

User trials involve students and teachers in elementary school. The evaluation of oneon-one and small group trials on product models developed includes assessing content, presentation and layout. The results of assessment data analysis on the one-on-one trials by 6 students from 10 statement items showed CVR $>0$. The value of CVR for each statement item amounted to 1,00 which means that each item was declared good. The results of assessment data analysis on small group trials by 36 students from 10 statement items showed CVR values $>0$. The value of CVR for each statement item amounted to 1.00 which means that each item was declared good. The results of the oneon-one trial evaluation data and small group trials by 8 teachers from 33 statement items showed CVR values $>0$. CVR Values for each statement item amounted to 1,00 which means each item was declared good.

From the results of user trials, it can be concluded that the product of the social studies learning model based on local wisdom are developed meets the requirements to be used in the real learning process.

\section{Research Question 3}

The Data of Model Implementation Results

\section{Students Knowledge}

Table 1

$\mathrm{T}$ test Results of Two Independent Samples of Students Knowledge Value of The Experiment and Control Class

\begin{tabular}{lll}
\hline Statistics & Experimental Class & Control Class \\
\hline $\mathrm{N}$ sample & 47 & 41 \\
\hline Average (Mean) & 32,43 & 13,54 \\
\hline Standard Deviation (SD) & 5,05 & 4,47 \\
\hline Variance & 25,47 & 20,00 \\
\hline $\mathrm{t}_{\text {count }}$ & 18,61 & \\
\hline $\mathrm{t}_{\text {table }}(\alpha=0,05)$ & 1,98 & \\
\hline
\end{tabular}

Based on table 1, the experimental class was attended by 47 students and the control class followed by 41 students. The value of the average knowledge of students for the experiments is higher, namely 32,43 than the value of the average knowledge of the control class is 13,54 . $T$ test results for student knowledge data show $t_{\text {count }}=18,61>$ of $t_{\text {table }}=1,98$ at significance $\alpha=0,05$, then $H_{0}$ rejected and accept $H_{1}$. So it is concluded the knowledge test result from the experimental group is higher than control group (it means the use of social studies teaching materials based on local wisdom is better than conventional materials in increasing students' knowledge).

Students Social Attitudes 
Table 2

$\mathrm{T}$ test Result of Two Independent Samples of Students Social Attitude Values of Experimental and Control Class

\begin{tabular}{|c|c|c|}
\hline Statistics & Experimental Class & Control Class \\
\hline N sample & 47 & 41 \\
\hline Average (Mean) & 51,72 & 46,80 \\
\hline Standard Deviation (SD) & 5,81 & 6,00 \\
\hline Variance & 33,74 & 36,01 \\
\hline $\mathrm{t}_{\text {count }}$ & 3,90 & \\
\hline $\mathrm{t}_{\text {table }}(\alpha=0,05)$ & 1,98 & \\
\hline
\end{tabular}

Based on table 2, the experimental class was attended by 47 students and the control class followed by 41 students. The value of the average social attitude of students for the experiments is higher, namely 51,72 than the value of the average social attitude of the control class is 46,80. T test results for students social attitudes showed $t_{\text {count }}=3,90>$ of $\mathrm{t}_{\text {table }}=1,98$ at the level of significance $\alpha=0,05, \mathrm{H}_{\mathrm{o}}$ rejected and accept $\mathrm{H}_{1}$. So it concluded the social attitude of students from the experimental group is higher than control group (it means that the use of social studies materials based on local wisdom is better than conventional teaching materials in improving social attitudes).

\section{DISCUSSION}

This study describes the product of social studies learning models based on local wisdom in fourth grade elementary school students. The products produced are social studies teaching materials. Before teaching materials are used first, the feasibility of the experts and users is assessed. The results of evaluations from experts and user in the fields shown that the instructional material developed are suitable for use. After that the instructional learning for one semester. The use of teaching materials is specifically oriented to see the achievement of learning in terms of students' cognitive and social attitudes. The domain of knowledge is oriented so that students are able to understand the material provided in accordance with basic competency standards and competencies. The attitude domain is oriented to help encourage the formation of students' social attitudes to be better in accordance with the ethics and morals contained in local wisdom. The use of materials based on local wisdom as a social study learning material provides positive results. can be seen from the increasing knowledge and social attitudes of students.

Local wisdom is one of the nation's special cultural heritages and very important to explored, maintained and learned to students through the learning process (Yuliana, Sriyati, \& Sanjaya, 2017). Local wisdom is an inherent from of identity from birth (Rahyono, 2015). The local wisdom of the nation of that starts from values, the rule in the family and then developed in the community. A positive value of local wisdom is the identifier of civilized society and local knowledge is used to guide human behavior and natural behavior which aims to harmonize humans with human and humans with nature (Kartika, 2016). Learning local wisdom is assumed to be same as learning about the culture around it. Cultural learning can strengthen moral values in society (Ratana-Ubol \& Henschke, 2015). 
Integrating local wisdom values inti learning text material is very important. Based on Purwati, Anggraini \& Kusniarti (2015) in their research revealed that (1) incorporating local wisdom in textbooks allows students to be aware of local wisdom and develop their character by sticking to the local wisdom that has been learned. As a result, students are equipped with the right shield to counter the negative effects of modernization and globalization; (2) accuracy in choosing text material is very important so as to enable students to not only gain knowledge, but build their character based on values that are appropriate to local wisdom. Thus, students, teachers, schools, and parents must be more careful in choosing textbooks to support better learning. Traditional knowledge of local wisdom can influence one's attitude to act positively on their environment (Sutikanti, Syulasmi, \& Ramadhani, 2017). The use of local wisdom can increase student's respect for their region's potential to improve students' good attitude (Yuliana at al., 2017).

Learning based on local wisdom is considered better than conventional learning because it is adapted to be daily context of the students so as to make learning more meaningful. It emphasizes a student-centered learning process. During contextual learning activities, students construct meaning based on their experiences so that learning not only improves learning outcomes but also critical thinking (Sung, Hwang, \& Chang, 2015). People are easier to remember when learning material is associated with what they already know (Olivier \& Bowler, 1996). Student-centered learning method effect student success, attitudes and motivations positively (Cepni, 2015).

The values of local wisdom that is integrated in social studies learning serve as a reflection with teachers and students to be studied, understood its meaning, applied in life and accustomed. A teacher must be able to set a good example so that will from the habits and positive attitudes or social attitudes in students. The philosophical values of local wisdom have a positive meaning that can reflect the student's attitude better.

The integration of local wisdom is method deemed appropriate in the development of the basic school learning curriculum and the implementation of local wisdom more emphasizes the role of teachers as mentors and managers of learning techniques without just holding the book (Pornpimon, Wallapha, \& Prayuth, 2014). Education developed by utilizing local wisdom will lead to the emergence of an independent attitude, full of initiative and creative (Wiyani, 2013).

According to Bakhtiar \& Nugroho (2015) that development of a local wisdom-based learning curriculum will support schools in educating students to act in harmony with the natural environment and will certainly solve local problems that impact on the global. Local wisdom can be the basis of character education in school (Sugiyo \& Purwastuti, 2017). Local wisdom-based learning is very concrete with the child's life. Faced with the concrete situation encountered, the learning provided by the teacher in school has relevance to the child's culture in the environment so that the learning given by the teacher in school has relevance to the child's culture in the environment so that learning is easy to accept and apply in his life. Cultural aspect contributes to the identity and self concept of learners and influences beliefs, values, attitudes, expectations, social relationships, language use and student behavior (Slavin, 2008). 
Increasing social knowledge and attitude in social studies subjects based on local wisdom can direct students as the nation's next generation who has broad insight and do not forget their own culture. This knowledge can be used to solve problems faced both locally and globally.

The implications of the research are : (1) fulfill the learning needs of the students contextually in the area of Muna district which is shown by the interest and enthusiasm in learning social studies, the material is easy to understand and more qualified learning so that the increase of knowledge and social attitude of the students, (2) facilitate teacher in conducting the learning process because it can be directly given examples close to the daily life of students so indirectly the students feel involved in learning, (3) can be used as a source of supporting references in local social studies learning both KTSP and K2013 curriculum (K-13).

\section{CONCLUSION}

1. The results of the experts and user's feasibility test on the product of the model of social studies learning based on local wisdom, it is stated that all the elements are considered appropriate and meet the requirements for use in regular learning or the actual learning process.

2. Different test (t-test) students' knowledge and social attitudes showed that the knowledge test results from the experimental group was higher than the control group, which meant that the use of local wisdom-based teaching materials was better or more effective than conventional teaching material in increasing students' knowledge and social attitudes.

3. The model of social studies learning based on local wisdom is a learning that is design according to context of the reality of everyday student life. Content preparation combined with local wisdom values. These values are used as a guide and direction for students in carrying out life. At the same time aiming at the process of regeneration the knowledge of the value of local wisdom to students early on well so it will not lose direction to act and behave. Education and real life synergized so as to create noble knowledge and character. Therefore, the product model of social studies learning based on local wisdom was deemed in accordance with learning needs. The product model of the development was proven to increase the knowledge and social attitude student class IV at SDN 6 Katobu and SDN 3 Batalaiworu in odd semester of the school year 2017/2018 in the Muna District Southeast Sulawesi Province.

\section{REFERENCES}

Anggraini, P., \& Kusniarti, T. (2015). The Insertion of local wisdom into Instructional Material of Bahasa Indonesia for $10^{\mathrm{Th}}$ Grade Students in Senior High School. Journal of Education and Practice, 6(33), 89-92.

Badan Standar Nasional Pendidikan. (2006). Standar isi untuk satuan pendidikan dasar dan menengah. Jakarta: Depdikbud. 
Bakhtiar, A. M., \& Nugroho, A. S. (2016). Curriculum development of environmental education based on local wisdom at elementary school. International Journal of Learning, Teaching and Educational, 15(3), 20-28.

Beaty, J. J. (2010). Observing development of the young child. New Jersey: Pearson.

Borg, W. R., \& Meredith, D. (1983). Educational research an introduction. New York: Pearson Educational.

Boyle-Baise, Marilynne, \& Zevin, J. (2009). Young citizens of the world. New York and London: Routledge Taylor \& Francis.

Carrington, S., \& Macarthur, J. (1968). Teaching in inclusive schools communities. Cina: John Willey \& Sons Australia.

Cepni, O. (2015). The problems that social studies teacher in encounter in learning and teaching process. International Online Journal of Educational Sciences, 7(4), 165-187.

Crapo, R. H. (2002). Cultural anthropology. New York: McGraw-Hill Companies.

Dodge, D. T., Rudick, S., \& Berke, K. (2006). The creative curriculum for infants, toddlers \& twos. United States of America: Teaching Strategies.

Gunawan, A. H., (2010). Sosiologi pendidikan. Jakarta: Rineka Cipta.

Guvercin, S., \& Verbovskiy, V. (2014). The effect of problem proposing tasks used in mathematics instruction to mathematics academic achievement and attitudes toward mathematics. International Online Journal of Primary Education, 3(2), 59-65.

Hweston, M., Stroebe, W., \& Jonas, K. (2010). An introduction to social psychology. United of America: John Wiley \& Sons.

Jackman, H. L. (2010). Early education a child's connection to the world. United States of America: Wadsworth Cengage Learning.

Kartika, T. (2016). Verbal communication culture and local wisdom: The value civilization of Indonesia nation. Lingua Cultura, 10(2), 89-93. Doi:10.21512/1c.v10i2.1424.

Kumari, B. V., \& Bhaskararao, D. (2004). Methods of teaching social studies. New Delhi: Dynamic Printers Delhi.

Lapiere, R. T. (2010). Attitudes vs action. International Journal of Epidemiology, 13(2), 7-11, doi: 10.1093/ije/dyp398.

Mayesky. (2012). Creative activities for young children. Unites State of America: Wadsworth Cengage Learning.

Miller, D. F. (2012). Positive child guidance. Unites State of America: Woodsworth Cengage Learning.

McAdams, M., \& Mulyana, D (Ed.). (2012). Cultures and communication. Bandung: Remaja Rosdakarya. 
Nata A. (2014). Sociologi pendidikan islam. Jakarta: Rajawali Pers

Nitko, A. J., (2001). Educational assessment of students. United States of America: Merrill Prentice Hall.

Olivier, C., \& Bowler, R. F. (1996). Learning to learn. United States of America: Fireside.

Ostrome. (1993). The evolution of norm, rules and right. Sweden Stockholm: The Royal Swedish Academy Science.

Parker, W. C. (2009). Social studies in elementary education. United Stated of America: Pearson Education.

Pornpimon, C., Wallapha, A., \& Prayuth C. (2014). Strategy challenges the local wisdom applications sustainability in school. Procedia-Social and Behavior Sciences. 112, 626-634.

Rahyono, F. X. (2015). Kearifan budaya dalam kata. Jakarta: Wedatama Widya Sastra.

Rohmadi, M., \& Hartono, L (Ed.). (2011). Kajian bahasa, sastra dan budaya jawa: teori dan pembelajarannya. Jakarta: Pelangi Press.

Ratana-Ubol, A., \& Henschke, J. A. (2015). Cultural learning processes through local wisdom: a case study on adult and lifelong learning in Thailand, International Journal of Adult Vocational Education and Technology, 6(2), 41-60.

Sabirova, E. G. (2016). Pedagogical guest room as an educational form of students' pedagogical competence development. International Journal of Environmental and Science Education, 11(6), 1059-1064.

Seefeldt, C., Castle, S., \& Falconer, R. C. (2010). Social studies for the preschool/primary child. New Jersey: Pearson Education.

Senge, P. Camron-McCabe, N., Lucas, T., Smith, B., Dutton, J., \& Kleiner, A. (2002). School that learn, a fifth discipline fieldbook for educators, parents, and everyone who cares about education. Finlandia: Nicholas Brealey Publishing.

Slavin, R. R. (2008). Psikologi pendidikan teori dan praktek. Jakarta: Indeks.

Surtikanti, H K., Syulasmi, A., \& Ramadhani, N. (2017). Traditional knowledge of local wisdom of Ammatoa kajang tribe (South Sulawesi) about environmental conservation. Journal of Physics, 895, 1-10. Doi: 10.1088/1742-6596/895/1/012122.

Sugiyo, R. L., \& Purwastuti, A. (2017). Local wisdom-based character education model in elementary school in Bantul Yogyakarta Indonesia. Sino-US English Teaching, 2017, 14(5), doi: 10.17265/1539-8072, .05.003.

Sung, H., Hwang, G., \& Chang, H. (2015). An integrated contextual and web-based issue quest approach to improving students' learning achievements, attitudes and critical thinking. Journal of Educational Technology, 18(4), 299-311. 
Suparman, M. A. (2014). Desain instruksional modern. Jakarta: Universitas Terbuka.

Tilaar, H. A. R. (2012). Perubahan sosial dan pendidikan. Jakarta: Grasindo.

Wade, R. C. (2007). Social studies social justice teaching strategies for the elementary classroom. New York: Teachers College Press.

Wiyani, N. A. (2013). Membumikan pendidikan karakter di SD konsep praktik dan strategi. Yogjakarta: Ar-Ruzz Media.

Yuliana, Sriyati, S., \& Sanjaya, Y. (2017). Local wisdom of ngata toro community in utilizing forest resources as a learning source of biology. The $4^{\text {th }}$ Inernational Conference on Researc, Implementation, and Education of Mathematics and Science (4 ${ }^{\text {th }}$ ICRIEMS): American Institute of Physics. doi: 10.1063/1.4995217. 